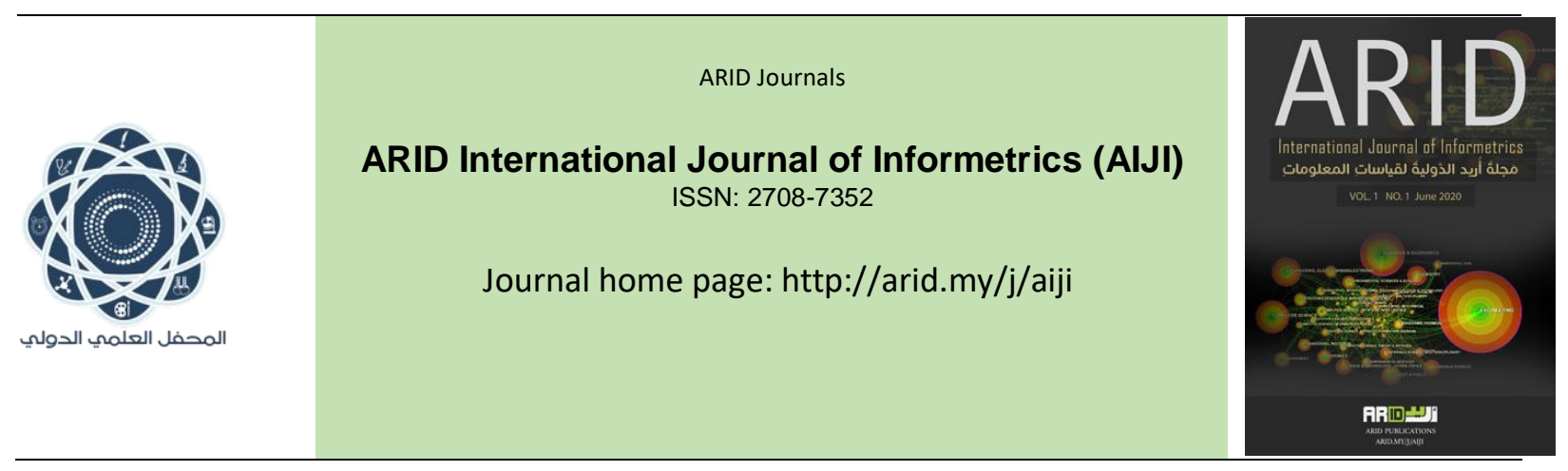

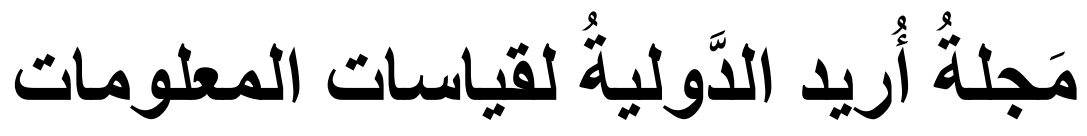 العدد 1 ، المجلد 1 ، تموز 2020 م
}

\section{A Scientometrics Study of the Research Productivity of Prince Mohammad Bin Fahd University in Scopus Database in Ten Years (2008 to 2018)}

\author{
Mohammed A. Abdulla ${ }^{1 *}$, Bimal Krishna Banik ${ }^{2}$
}

\section{1- Deanship of Research, Prince Mohammad Bin Fahd University, Saudi Arabia}

2- Deanship of Research Development; Department of Mathematics and Natural Sciences, Saudi Arabia

دراسة لقياس الإنتاجية البحثية لجامعة الأمير محمد بن فه في قاعدة بيانات سكوبس في عشر سنوات (2018-2008)

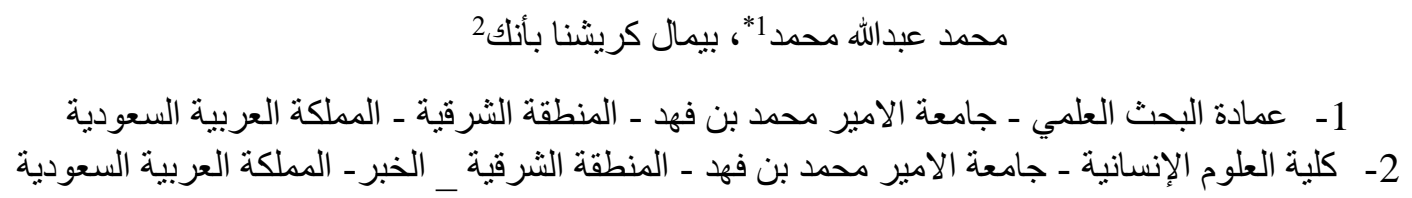

mabdulla@pmu.edu.sa

arid.my/0001-2471

https://doi.org/10.36772/arid.aiji.2020.116 


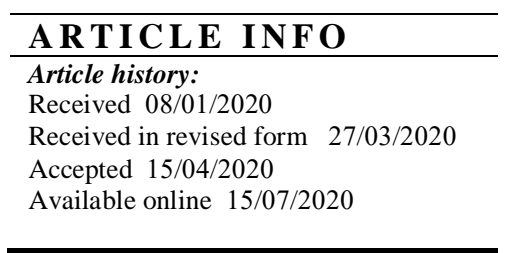

\section{ABSTRACT}

This paper describes the scientometric study of faculty member's research productivity at Prince Mohammed Bin Fahd University (PMU) in Khobar, Saudi Arabia. The study aims to evaluate the research performances of the faculty members at Mohammed Bin Fahd University, researchers and graduate students for the last 10 years. PMU was established in 2008 and data is collected for this case study from Scopus database during 2008-2018. This study has analyzed approximately 609 scientific research publications over 10 years. These publications include 434 research papers, 143 conference proceedings, 15 book chapters, 11 reviews, and 2 Erratum. The current study highlights the active researchers of the PMU, their fields, and the journals in which they published their research work. An evaluation of their research productivity in terms of publishing, citations, and H-index is also described. The paper also analyzes the significant differences between the averages of research productivity level for the PMU faculty members due to the variables ranking, and the difficulties for research production from the opinion of the faculty members.

Keywords: Scientometric study, Scopus database, PMU, Prince Mohamed Bin Fahd University, Research productivity. 


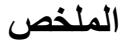

الدراسة تصف وتحلل الإنتاجية البحثية لأعضاء هيئة التدريس بجامعة الأمير محمد بن فهد في مدينة الخبر، المملكة العربية السعودية. و تهدف الدراسة إلى تقييم الأداء البحثي لأعضاء هيئة التدريس في جامعة محمد بن فهد والباحثين وطلاب

الدر اسات العليا على مدى عثر سنوات، حيث تأسست عمادة البحوث بالجامعة في عام 2008، وقد تم جمع البيانات للدر اسة من قاعدة بيانات سكوبس خلال الفترة مابين 2008-2018. حيث تم در اسة وتحليل ما يقارب 609 مادة علمية على مدى 10 سنوات. وتثمل هذه المواد العلمية عدد (434) ورقة بحثية، وعدد (143) من ورقة علمية مقدمة لمؤتمرات، و عدد (15) فصل لكتاب، و عدد (11) مر اجعات علمية، و عدد (2) تحقيق. تسلط الدر اسة الحالية الضوء على الباحثين النشطين في جامعة الامير محمد بن فهر ومجالاتهم البحثية والمجلات الأكاديمية التي نشروا فيها أعمالهم البحثية. تم وصف وتقييم إنتاجية أبحاثهم من حيث عدد الأعمال المنشورة و عدد الاستشهادات المرجعية ومعدل معامل التأثير (H). كما تم تحليل الفروق ذات الدلالات الإحصائية بين متوسطات مستوى الإنتاجية البحثية لأعضاء هيئة التدريس في الجامعة بسبب ترتيب المتغير ات، وصعوبات الإنتاج البحثي من وجهة نظر أعضاء هيئة التدريس. الكلمات المفتاحية : تحليل المؤلفات العلمية، قاعدة إسكوباس، جامعة الأمير محمد بن فهد، الإنتاجية البحثية. 


\section{Introduction}

\section{a- Problem statement}

This paper explores the measurement and analysis of the research productivity of Prince Mohammad Bin Fahd University based upon the Scopus Databases in ten years (2008 to 2018). The current study examined (609 publications) affiliated by Prince Mohammad Bin Fahd University during ten years, to recognize the year-wise publications and productivity, most productive type publications, Publications subject areas-wise distribution and department-wise distribution of colleges, most prolific author, Authorship pattern in research publication, and measure these publications with discovering the distribution of the total citations.

\section{b- Objectives}

This study aims to achieve the following goals:

1. To identify the academic research productivity of Prince Mohammed Bin Fahd University in Scopus database.

2. To analyzes the significant differences between the averages of research productivity level for the PMU faculty members due to the variables ranking.

3. To find the difficulties for scientific production at Prince Mohammed Bin Fahd University from the view of the faculty members.

4. To evaluate the citations of research productivity of Prince Mohammed Bin Fahd University academic in Scopus database. 


\section{c- Research questions}

This study seeks to answer the following questions:

1. How many publications are published in the Scopus database with Prince Mohammed Bin Fahd University affiliation?

2. What are the significant differences between the averages of research productivity level for the PMU faculty members due to the variables ranking?

3. What are the difficulties for scientific productivity at Prince Mohammed Bin Fahd University from the view of the faculty members?

4. What identify the level of Prince Mohammed Bin Fahd University academic Research productivity in Scopus database?

5. What is the scientific and academic impact of using citations with the affiliations of the Prince Mohammed Bin Fahd University in Scopus?

\section{Material and methods}

Scientometrics is the quantitative study of various disciplines of science based on published literature and communication. This could include identifying emerging areas of scientific research, examining the development of research over time, and geographic and organizational distributions of research (The Thompson Corporation, 2008).

Scientometrics study is the study of measurement and analysis of science, technology and innovation. Major research issues include impact measurement, reference groups of materials to investigate the impact of journals and institutes, understanding of scientific citations, mapping scientific fields and production of indicators for use in policy and management contexts (Ceballos, 
2017). The field of study concerns itself with measuring and analysing scientific literature.

Scientometrics is a sub-field of bibliometrics. Major research issues include the measurement of the impact of research papers and academic journals, the understanding of scientific citations, and the use of such measurements in policy and management contexts (Suresh \& Thanuskodi, 2020). Scientometrics is the study of science, technology, and innovation from a quantitative perspective (Leydesdorff, 2012). It can be defined as the "quantitative study of science, communication in science, and science policy" (Hess, 1997).

\section{Literature review}

The importance of scientific research has increased as the main pillar that makes up the comprehensive development plans of a research center or university. This has become an important and reliable asset to the realization of the Saudi Vision 2030 through the construction and formation of the knowledge in the Kingdom. The universities are taking measures to the development of research capabilities, the qualification of researchers, and attracting competencies. These are highly necessary in order to work in research projects where the evaluation of universities at the global rank is measured mainly by the scientific research productivity (Al-Attiyah, 2018). Interest in the study of scientific communication, in general, has increased, particularly through publishing papers in scientific journals indexed in Scopus or ISI. These are also followed under several names, including bibliometrics study and a Scientometrics studies as new scientific fields. Therefore, Scientometrics Study of the PMU Research Productivity in Scopus Database in ten years (2008 to 2018) to measuring and analysing scientific publications affiliated by Prince Mohammad Bin Fahd University is one of the goals of this study. Satish Kumar (2018) analyzed the scientific productivity of 
Aryabhatta Research Institute of Observational Sciences (ARIES) both in the number of publications and the quality of the publication and trend of research. This study identified that ARIES scientists are working actively to increase their research productivity, as well as they published in high impact factor journals. Dillip K. Swain (2013) examined the research productivity of KIIT University, by evaluating 361 publications indexed in Scopus from the year 2000 to 2013. The study found KIIT University publications in Scopus since the year 2008 and the year 2011. This was the greatest productive time since 107 articles were published. The top authors had published 25 articles, and the university had $\mathrm{h}$ index of 11 . Vimlesh Patel and N S Thakur (2018) conducted Scientometric analysis of Research productivity of National Environmental Engineering Research Institute, Nagpur, during 2012 to 2016 following ISI (Web of Science database). The study discovered the growth of research productivity during the study period with respect to total number of papers. These articles were published in literature (90.98\%). This was found that Council of Scientific Industrial Research, India ranked first with 377 documents $(94.49 \%)$. The highly productive subject areas were Environmental Sciences and Ecology with 34.34\%, followed by Engineering with $19.30 \%$, and Chemistry with $16.79 \%$ of the total publications. The USA and Japan had contributed most of the scientific papers. S. Jeyachitra, J. Santhi, K. Rajaram (2017) evaluated and analyzed the research productivity of faculty member in the Urumu Dhanalakshmi College, India. The study examined 106 publications in 1994 to 2016 indexed by Google Scholar. The study found the year-wise distribution of publication, most productive author, journal-wise distribution and gender-wise distribution of authors. Héctor G. Ceballos and others (2017) conducted a study under the title "Impelling research productivity and impact through collaboration at a Mexican university". This study summarized data for 15 years, and evaluated 2400 researchers, 24,000 publications and 15 research disciplines. R Senthilkumar, G Ulaganathan (2015) analyzed the research productivity at the University of Madras. The study showed among the published 712 
publications, 78 (10.96\%) publications are published during $2011 \& 2013$ and 39 (5.48\%) publications are published in 2006. At the same time 506 citations were noted; 138 (27.27\%) citations in 2004 and $2(0.40 \%)$ citations in 2015.

\section{Prince Mohammad Bin Fahd University affiliation in Scopus:}

Prince Mohammad Bin Fahd University has given priority to scientific and applied research and has taken serious initiatives to transform the University research-oriented. In this regard, PMU has established the University Research Center under which a number of research professors are recruited and various research centers on emerging areas of research are created. PMU has also established a Patent Center to support faculty, staff and students in documenting and registering their intellectual properties. The University has provided and continued to provide its faculty, students and staff with the necessary resources, tools, and environment to conduct research with high impact. As a result of PMU commitment to research, its distinguished faculty members have significantly improved their productivity. This is evident in the sharp increase in research publications in the Scopus database under the University affiliation. Since science and technology is global in nature, the University has developed several international research collaborative partnerships. The fostering internationalization of PMU faculty and researchers as well as its students through collaborative research, visits and exchange programs has proven to be indispensable. 
Analysis of Prince Mohammad Bin Fahd University data in Scopus:

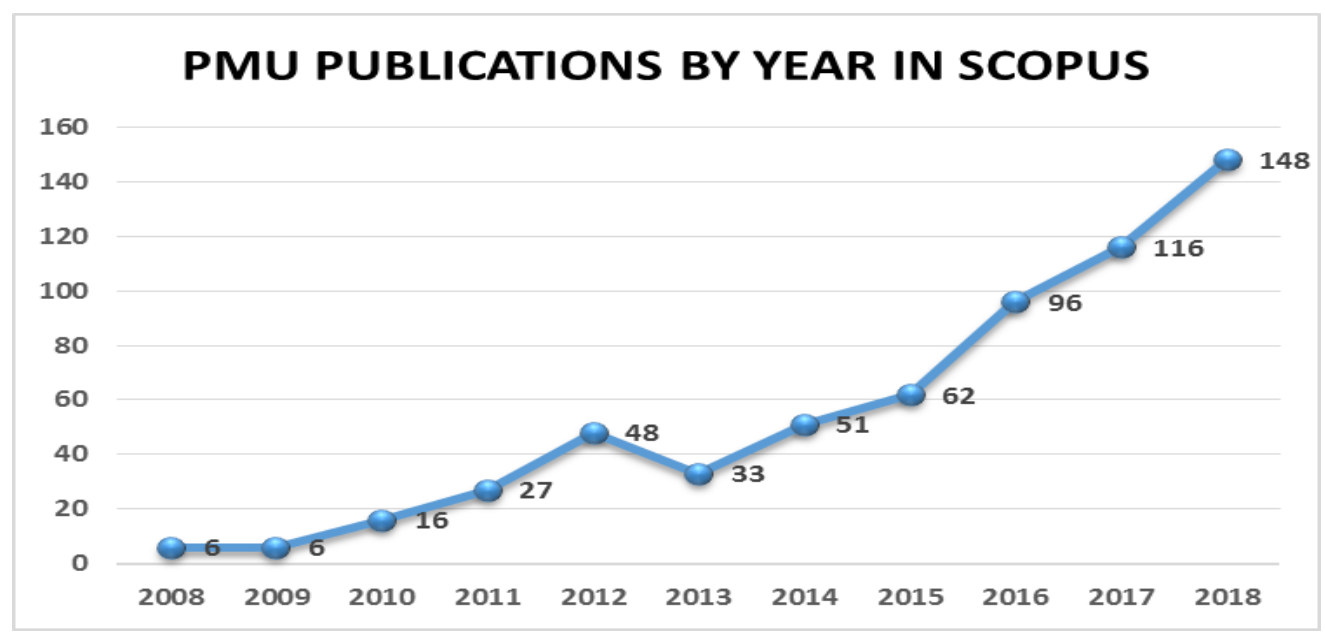

Figure 1: PMU Publications over 10 years

Figure (1) shows the research performance in Scopus of Prince Mohammed Bin Fahd University during the ten years 2008 to 2018. It is noted that there is a year-wise increase of research productivity. But in 2013 , the productivity has decreased from 48 publications in 2012 to 33 publications in 2013. However, in 201451 papers are published.

PMU Publications in Scopus sorting by document type

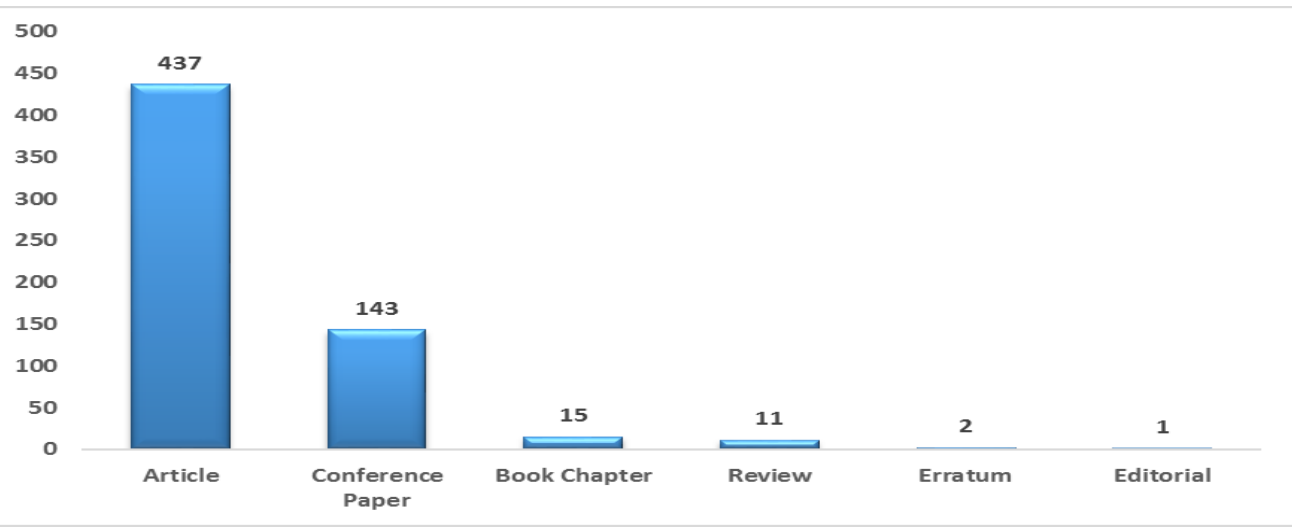

Figure 2: PMU Publications in Scopus by document type 
Figure (2) bar chart shows the Prince Mohammad Bin Fahd University Publications in Scopus. Out of these, research articles (437 publications), conference papers representing (143 publications), book chapters (15), review (11 publications), (2) erratum, and (1) editorial are published.

\section{PMU Publications in Scopus sorting by source type}

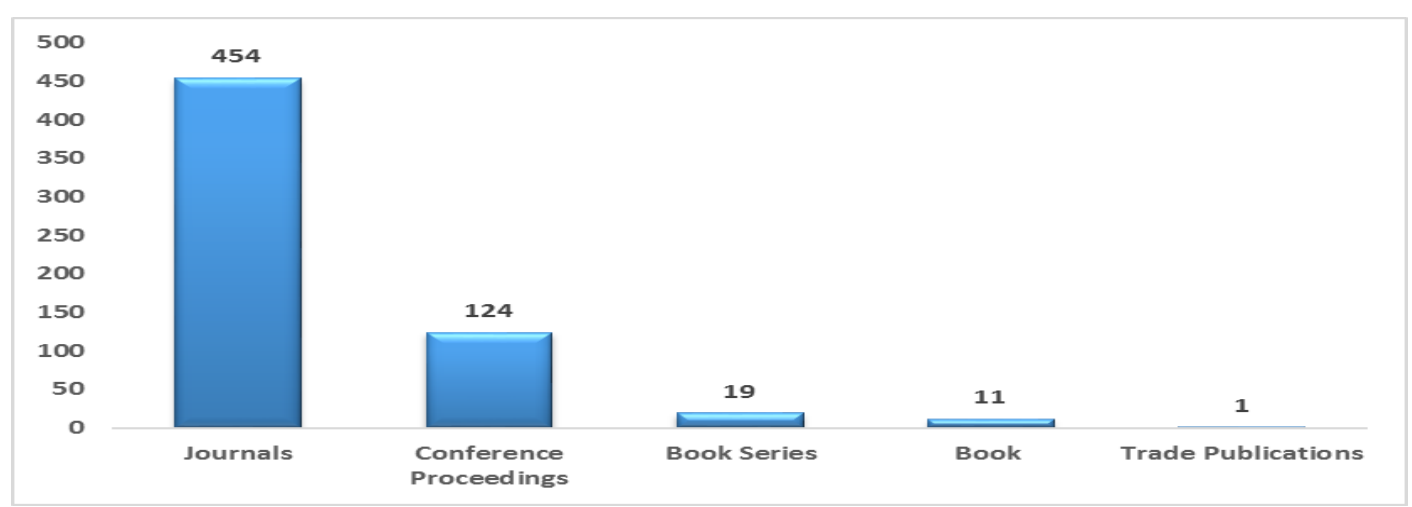

Figure 3: PMU publications in Scopus sorting by source type

Figure (3) bar chart shows the Prince Mohammad Bin Fahd University Publications in Scopus sort by source type, The most publications for Prince Mohammad Bin Fahd University published in scientific journals (454 publications), followed by conference proceeding (124 publications), books series (19 publications), books (11 publications), and trade publications $(1)$. 


\section{PMU Publications in Scopus in 10 top Subject area}

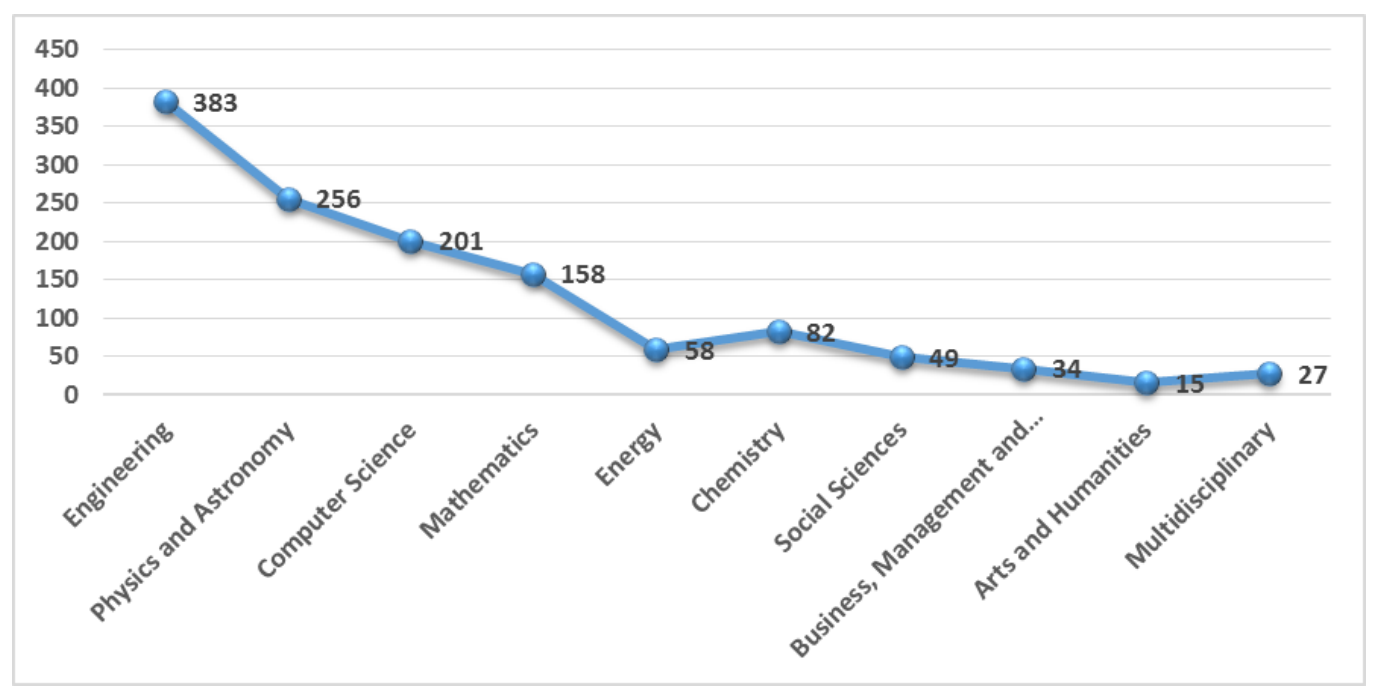

Figure 4: PMU publications in Scopus sorting by source type

Figure (4) shows the Prince Mohammad Bin Fahd University Publications in Scopus in 10 areas. The number of publications in different disciplines are as follows : Engineering (383 publications), Physics and Astronomy (256 publications), Computer Science (201 publications), Mathematics (158 publications), Energy (58 publications), Chemistry (82 publications), Social science (49 publications), Business (34 publications), and Arts and Humanities (15 publications). 


\section{PMU Publications in Scopus by college}

Table 1: PMU Publications in Scopus by college

\begin{tabular}{|l|c|}
\hline \multicolumn{1}{|c|}{ College } & Total publications Number \\
\hline College of Engineering & 321 \\
\hline $\begin{array}{l}\text { College of Computer Science and } \\
\text { Engineering }\end{array}$ & 140 \\
\hline College of Science and Human Studies & 116 \\
\hline College of Business Administration & 32 \\
\hline College of Law & 0 \\
\hline
\end{tabular}

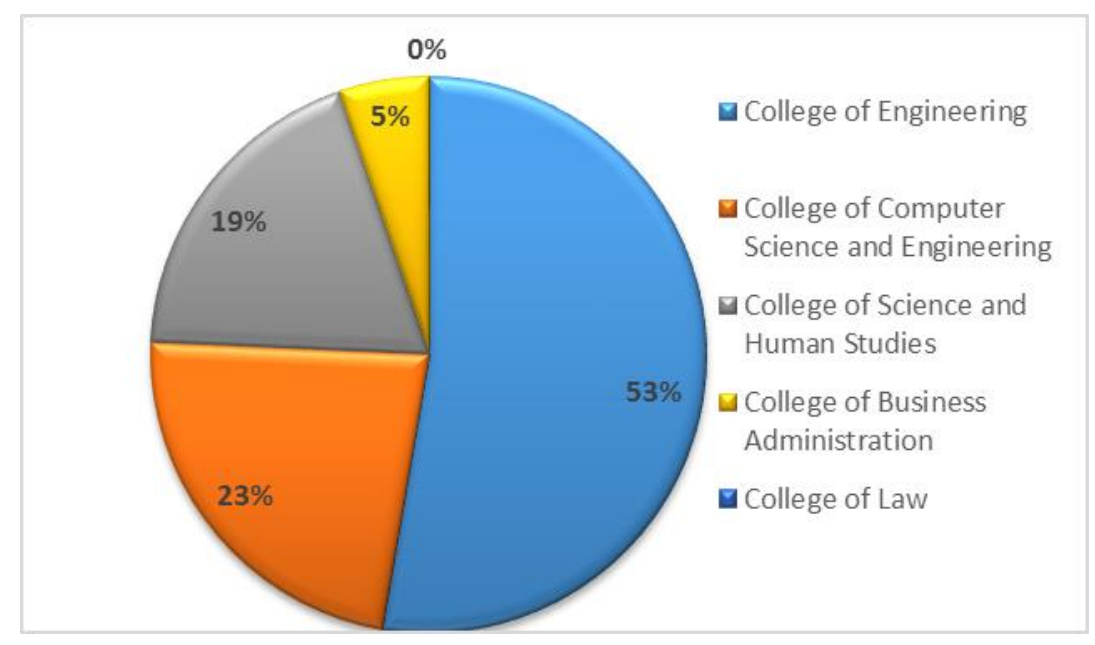

Figure 5.PMU Publications in Scopus by college

Table (1) and figure (5) shows that the Faculty of Engineering has the maximum research productivity with $53 \%$ of total publications. The rest of the other colleges shares a combined $57 \%$ of the total publications. The College of Computer Engineering has (140 publications) 23\%, followed by college of Science and Human Studies (116 publications) 19\%, and College of Business Administration 32. 


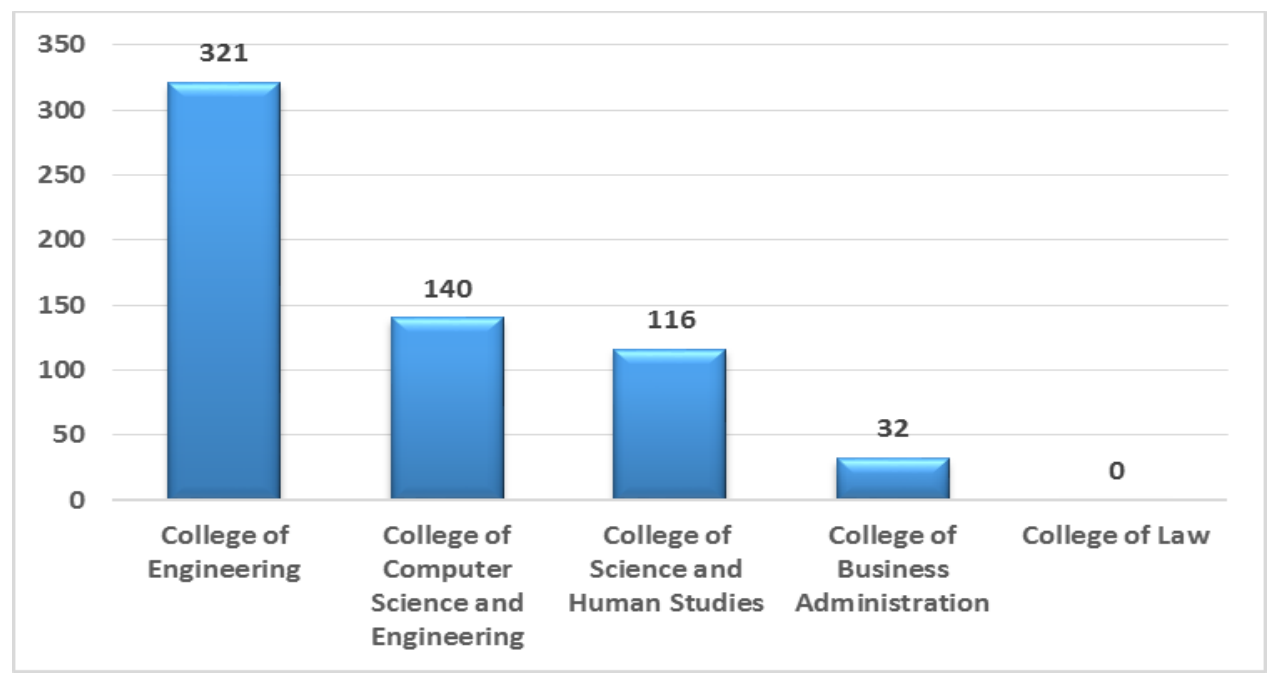

Figure 6: PMU publications in Scopus sorting by college

\section{PMU Publications in Scopus and citation}

Table 2: PMU Publications and citations in Scopus database

\begin{tabular}{|c|c|c|}
\hline Year & $\begin{array}{c}\text { Number of } \\
\text { publications }\end{array}$ & Total citation No \\
\hline 2008 & 6 & 384 \\
\hline 2009 & 6 & 8 \\
\hline 2010 & 16 & 138 \\
\hline 2011 & 27 & 51 \\
\hline 2012 & 48 & 278 \\
\hline 2013 & 33 & 273 \\
\hline 2014 & 51 & 338 \\
\hline 2015 & 62 & 553 \\
\hline 2016 & 96 & 1676 \\
\hline 2017 & 116 & 1806 \\
\hline 2018 & 148 & 977 \\
\hline Total & 609 & 6482 \\
\hline
\end{tabular}

The above table (2) clearly shows that the total citation for Prince Mohammad Bin Fahd University in Scopus during 2008 to 2018 is 6482 which are distributed according to the following diagram: 


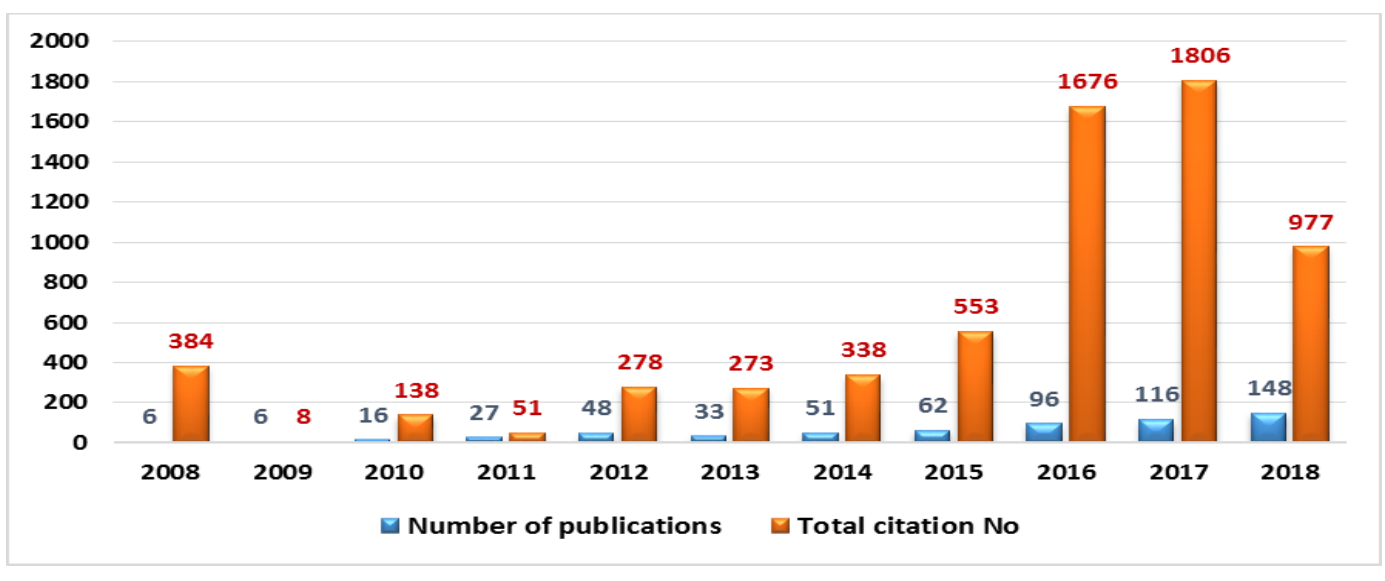

Figure 7: Publications and citations in Scopus database

From above diagram (figure 7) it is seen that there is a significant increase in citation in the year 2016 and 2017. This is an indication that the papers of PMU during these two years were published in the high impact factor journals. Also, the citation number distribution with esteem publications total number in each year

\section{Top 10 PMU Collaborative Research in Scopus by countries}

Table 3: PMU Publications in Scopus sorting by collaborating countries

\begin{tabular}{|l|c|c|}
\hline \multicolumn{1}{|c|}{ Top 10 Country } & Collaborative Publications & Percentage \\
\hline Saudi Arabia & 608 & $55.6 \%$ \\
\hline India & 106 & $10.6 \%$ \\
\hline Iran & 66 & $6 \%$ \\
\hline Pakistan & 65 & $5.9 \%$ \\
\hline United Arab Emirates & 63 & $5.7 \%$ \\
\hline United states & 51 & $4.6 \%$ \\
\hline Malaysia & 43 & $3.9 \%$ \\
\hline United Kingdom & 33 & $3 \%$ \\
\hline Australia & 29 & $2.6 \%$ \\
\hline Canada & 28 & $2.5 \%$ \\
\hline
\end{tabular}


Table (3) shows the top 10 collaborative countries with Prince Mohammad Bin Fahd University (PMU). The table indicates that internal cooperation of PMU in Saudi Arabia has resulted in 608 publications. Similar collaborations with India has resulted in 106 publications, followed by Iran with 66 publications, Pakistan with 65 publications, United Arab Emirates with 63 publications, United States with 51 publications, Malaysia with 43 publications, United Kingdom with 33 publications, Australia with 29 publications, and Canada with 28 publications.

Top 10 Highly productive Authors at PMU during 2008-2018

Table 4: Top 10 highly productive Authors at PMU in Scopus database

\begin{tabular}{|l|c|c|c|c|c|}
\hline \multicolumn{1}{|c|}{ Faculty Name } & Position & $\begin{array}{c}\text { No of } \\
\text { publications }\end{array}$ & Percentage & $\begin{array}{c}\text { Total } \\
\text { Citation }\end{array}$ & $\begin{array}{c}\text { H- } \\
\text { Index }\end{array}$ \\
\hline Chamkha, Ali Jawad & 208 & $59.9 \%$ & 13166 & 64 \\
\hline Sawalhi, Nader M & 26 & $7.4 \%$ & 1376 & 14 \\
\hline Djavanroodi, F & 21 & $6 \%$ & 853 & 17 \\
\hline $\begin{array}{l}\text { Muhammad, } \\
\text { Shahabuddin }\end{array}$ & 12 & $3.4 \%$ & 79 & 6 \\
\hline Ashraf, Waqar & 11 & $3.1 \%$ & 760 & 15 \\
\hline Asiz, Andi & 11 & $3.1 \%$ & 153 & 6 \\
\hline Bashar, Abul & 11 & $3.1 \%$ & 66 & 5 \\
\hline Latif, Ghazanfar & 11 & $3.1 \%$ & 38 & 4 \\
\hline Saleem, Najma & 11 & $3.1 \%$ & 163 & 7 \\
\hline $\begin{array}{l}\text { Mohammad, } \\
\text { Nazeeruddin }\end{array}$ & 10 & $2.8 \%$ & 82 & 3 \\
\hline Asad, Muhammad & & 8 & $2.3 \%$ & 277 & 7 \\
\hline Alghazo, Jaafar M. & & 7 & $2 \%$ & 52 & 3 \\
\hline Total & & & & \\
\hline
\end{tabular}

Table (4) shows the top 10 active researchers at Prince Mohammed bin Fahd university during the period from 2008 to 2018.It is noted that half of the research output in Scopus is carried 
out by only 10 active researchers at a time when there are more than 170 faculty members PhD holders, There is no convergence among the 10 active researchers themselves, for example, Ali Chamkha published $60 \%$ of the research output of the 10 active researchers, and he published $34 \%$ of all the research output of the PMU during the 10 years.

Also, for citations and H-Index Ali Chamkha achieved the highest number (13166 citations) and $64 \mathrm{H}-$-ndex, followed by Nader Sawalhi (1376 Citation) and H-Index14, outdone by Djavanroodi, F with H-Index 17 and (853 citations).

\section{Authorship Pattern of PMU Publications in Scopus}

Table 5: Authorship Pattern of PMU Publications at PMU in Scopus database

\begin{tabular}{|c|c|c|c|c|c|}
\hline Year & $\begin{array}{c}\text { One } \\
\text { Author }\end{array}$ & $\begin{array}{c}\text { Two } \\
\text { Author }\end{array}$ & $\begin{array}{c}\text { Three } \\
\text { Author }\end{array}$ & $\begin{array}{c}\text { More than } \\
\text { three }\end{array}$ & $\begin{array}{c}\text { Total } \\
\text { publications }\end{array}$ \\
\hline 2008 & 2 & 3 & 0 & 1 & 6 \\
\hline 2009 & 2 & 4 & 0 & 0 & 6 \\
\hline 2010 & 2 & 4 & 4 & 6 & 16 \\
\hline 2011 & 5 & 5 & 15 & 2 & 27 \\
\hline 2012 & 16 & 13 & 10 & 9 & 48 \\
\hline 2013 & 6 & 16 & 5 & 6 & 33 \\
\hline 2014 & 8 & 19 & 9 & 15 & 51 \\
\hline 2015 & 6 & 20 & 19 & 17 & 62 \\
\hline 2016 & 11 & 16 & 39 & 30 & 96 \\
\hline 2017 & 5 & 12 & 38 & 61 & 116 \\
\hline 2018 & 6 & 19 & 33 & 90 & 148 \\
\hline Total & 69 & 131 & 172 & 237 & 609 \\
\hline
\end{tabular}

In order to determine the strength of research cooperation (Degree of Collaboration), Subramaniam k (1983) presented the following formula: $\mathrm{DC}=\mathrm{Nm} /(\mathrm{Nm}+\mathrm{Ns})$

$(\mathrm{C}=$ Degree of Collaboration in a discipline, $\mathrm{Nm}=$ Number of Multiple Authored research papers and Ns = Number of Single Authored research papers published during the same year). $C=540 / 540+69=0.47$. From the table above, the degree of collaborative research during 2008- 
2018 at Prince Mohammad Bin Fahd University is 0.47 this data clearly supports appropriate level of collaboration of the faculty orated research publication at PMU.

\section{Results}

Since its inception, Prince Mohammad Bin Fahd University has concentrated on teaching to deliver quality education to students with little emphasis on research. In the past four years since 2014, the university has emphasized research and many initiatives have been taken in order to transform the university into research-oriented. Toward this goal, the university has concentrated to hire international researchers who can perform teaching and conduct research effectively at the same time. As a result, many researchers have joined PMU. This helps the university in its research goals in some ways. For example, international collaborations have increased through additional research productivity and the deanship of research initiatives has created new policies and procedures to encourage faculty to be involved in research in their respective fields. Many diverse programs have been created. Some of these include Summer research contract, Patents and Licensing Policy, Internal Grant Proposal Review-policy, Endorsement and Pre-Approval Policy, PMU Research Award Criteria Policy, Payment for Open Access Journals policy, and Faculty Reduced Teaching Policy. The deanship of research has also started to focus on international researchers and hire some of them to join PMU as full-time research faculty. On the other hand, PMU has started to establish Research centers and labs (Cybersecurity center, PMU Research Center, Prince Mohammad bin Fahd Center for Futuristic Studies, The Center for Research Development, etc). These efforts will enhance the output in research and make international collaborations superior within a few years. 


\section{Discussion}

Prince Mohammed Bin Fahd University has become stronger in promoting research at all levels. However, the impact of research done at PMU must reach beyond the walls of the institution to the national, regional and global level. Through this study it becomes clear that additional Faculty, researchers and graduate students are necessary to conduct research at PMU. It is necessary that PMU faculty can apply for the external fund, participate in national and international conferences. It is important to mention that Prince Mohammad Bin Fahd University is a private university with limited fund and no funding is available from the government at this time. This was the reasons that a private university like PMU was concentrating on quality of education to the students. The University was eager to identify positions for the students in local industries. Because of the new initiation as described here, research productivity will be increased significantly in the near future.

\section{Conclusions}

This study explores the factors of research productivity of Prince Mohammad Bin Fahd University from 2008 to 2018. The ranking of PMU colleges is performed through focusing on published articles in high impact factor Journals indexed in Scopus database, and analyzing publications in terms of quantity, quality, subject coverage and type of publications.

There is a clear indication of significant increase in research productivity in Scopus for Prince Mohammad Bin Fahd University since the opening of the university to 2018. A maximum number of publications is published in high impact factor international journals followed by conference proceeding. The study has shown that Engineering College has published highest number (53\%) of publications through their various departments. The study analyses citations of PMU publications and compared them with that of obtained during 2008-2018. There is a need to encourage faculty members in the faculties of business management, law and humanities, and 
social sciences through providing the new tools to help in scientific publishing. Most faculty members belong to these colleges believe Scopus-indexed journals are not available in their fields.

\section{Acknowledgement:}

The authors would like to gratefully acknowledge the Deanship of Research at the prince Mohammad Bin Fahd for contributing in this study.

\section{Conflicts of interest:}

None declared under financial, general, and institutional interests. 


\section{References}

Al-Attiyah, A. (2018). Scientific research in Saudi universities and new jobs. Makkah Al Mukarramah.

Ceballos, Héctor G., FangmeyerJr., James, Galeano, Nathalíe, Juarez, Erika, Cantu-Ortiz, Francisco J. (2017). Impelling research productivity and impact through collaboration: a scientometric case study of knowledge management. Knowledge Management Research \& Practice15،(3)346 ، -355. DOI: 10.1057/s41275-017-0064-8.

Correia, António ‘Paredes, Hugo gFonseca, Benjamim. (2018). Scientometric analysis of scientific publications in CSCW. Scientometrics1،(114).

Glossary of Thompson Scientific Terminology (2008). The Thompson Corporation. Retrieved 23, 2020, from http://science.thomsonreuters.com/support/patents/patinf/terms.

Hess, D. J. Science Studies: An advanced introduction. New York: New York University Press، 1997.

Jeyachitra, S. ،Santhi, J. Rajaram, K. (2017). Research Productivity of Faculty Members in Urumu Dhanalakshmi College: A Scientometric Study. Journal of Advancements in Library Sciences ، 4(3) 31 r-37p.

Kumar, Satish. (2018). Scientometric study of Research productivity of ARIES, Nainital. Library Philosophy and Practice (e-journal)،1680 .

Leydesdorff, Loet, Milojević, Staša. (2012). Scientometrics, Cornel University: Digital libraries. https://arxiv.org/abs/1208.4566.

Patel, Vimlesh פThakur, N S. (2018). Scientometric analysis of Research productivity: a case study of National Environmental Engineering Research Institute, Nagpur. International Journal of Library Information Network and Knowledge3 ،(1). 
Suresh, N., Thanuskodi, S. (2020). Research Output on Maize (Zea Mays): A Scientometrics Study. Handbook of Research on Digital Content Management and Development in Modern Libraries. DOI: 10.4018

Swain, Dillip K. ‘Rautaray, Dr. Bijayalaxmi 9Swain, Dr. Chandrakanta. (2013). Scientometric Dimension of Research Productivity of a Leading Private University in India. Library Philosophy and Practice (ejournal)،933 .

Subramanyam, K. (1983). Bibliometric studies of research collaboration. Journal of Information Science6 $6(1) \times 33-38$.

Wright, James D. ‘Lynch, Michael, al, et. (2015). The International Encyclopedia of Social and Behavioral Sciences, Section 8.5: Science and Technology Studies, Subsection 85030, 2nd. 